\title{
Effects of unionized ammonia and suspended solids on rainbow trout (Oncorhynchus mykiss) in recirculating aquaculture systems
}

Becke, Cornelius; Schumann, Mark; Steinhagen, Dieter; Rojas-Tirado, Paula Andrea; Geist, Juergen; Brinker, Alexander

\section{Published in:}

Aquaculture

Link to article, DOI:

10.1016/j.aquaculture.2018.09.048

Publication date:

2018

Document Version

Peer reviewed version

Link back to DTU Orbit

Citation (APA):

Becke, C., Schumann, M., Steinhagen, D., Rojas-Tirado, P. A., Geist, J., \& Brinker, A. (2018). Effects of unionized ammonia and suspended solids on rainbow trout (Oncorhynchus mykiss) in recirculating aquaculture systems. Aquaculture, 499, 348-357. https://doi.org/10.1016/j.aquaculture.2018.09.048

\section{General rights}

Copyright and moral rights for the publications made accessible in the public portal are retained by the authors and/or other copyright owners and it is a condition of accessing publications that users recognise and abide by the legal requirements associated with these rights.

- Users may download and print one copy of any publication from the public portal for the purpose of private study or research.

- You may not further distribute the material or use it for any profit-making activity or commercial gain

- You may freely distribute the URL identifying the publication in the public portal 


\section{Accepted Manuscript}

Effects of unionized ammonia and suspended solids on rainbow trout (Oncorhynchus mykiss) in recirculating aquaculture systems

Cornelius Becke, Mark Schumann, Dieter Steinhagen, Paula Rojas-Tirado, Juergen Geist, Alexander Brinker

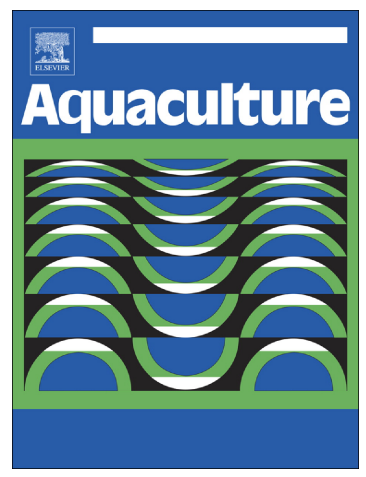

PII: $\quad$ S0044-8486(18)31503-5

DOI: doi:10.1016/j.aquaculture.2018.09.048

Reference: AQUA 633572

To appear in: aquaculture

Received date: $\quad 11$ July 2018

Revised date: $\quad 24$ September 2018

Accepted date: $\quad 25$ September 2018

Please cite this article as: Cornelius Becke, Mark Schumann, Dieter Steinhagen, Paula Rojas-Tirado, Juergen Geist, Alexander Brinker, Effects of unionized ammonia and suspended solids on rainbow trout (Oncorhynchus mykiss) in recirculating aquaculture systems. Aqua (2018), doi:10.1016/j.aquaculture.2018.09.048

This is a PDF file of an unedited manuscript that has been accepted for publication. As a service to our customers we are providing this early version of the manuscript. The manuscript will undergo copyediting, typesetting, and review of the resulting proof before it is published in its final form. Please note that during the production process errors may be discovered which could affect the content, and all legal disclaimers that apply to the journal pertain. 
1 Effects of unionized ammonia and suspended solids on rainbow trout (Oncorhynchus

2 mykiss) in recirculating aquaculture systems

4 Cornelius Becke ${ }^{\mathrm{a}, \star}$, Mark Schumann ${ }^{\mathrm{a}}$, Dieter Steinhagen ${ }^{\mathrm{b}}$, Paula Rojas-Tirado ${ }^{\mathrm{c}, \mathrm{d}}$, Juergen

5 Geist $^{\mathrm{e}}$, Alexander Brinker ${ }^{\mathrm{a}, \mathrm{f}}$

6

7 aFisheries Research Station of Baden-Württemberg, Argenweg 50/1, 88085 Langenargen,

8 Germany

9 bish Disease Research Unit, University of Veterinary Medicine Hannover, Bünteweg 17,

1030559 Hannover, Germany

$11{ }^{\mathrm{C}}$ Technical University of Denmark, DTU Aqua, Section for Aquaculture, The North Sea

12 Research Centre, P.O. Box 101, DK-9850 Hirtshals, Denmark

$13{ }^{\mathrm{d}}$ Norwegian Institute for Water Research, NIVA, Section for Aquaculture, Thormøhlensgate

14 53D, 5006 Bergen, Norway

15 e Chair of Aquatic Systems Biology, Department of Ecology and Ecosystem Management,

16 Technical University of Munich, Mühlenweg 22, 85354 Freising, Germany

17 fUniversity of Konstanz, Mainaustraße 252, 78464 Konstanz, Germany

18

19 * Corresponding author at: Fisheries Research Station of Baden-Württemberg,

20 Argenweg 50/1, 88085 Langenargen, Germany. Tel.: +49 7543/9308337;

21 fax: +49 7543/9308320. E-mail address: cornelius.becke@lazbw.bwl.de 
Abstract

23 This study investigates the individual and combined effects of chronic exposure of rainbow

24 trout to unionized ammonia and suspended solids in a farm-scale recirculating aquaculture

25 system (RAS) over 13 weeks. Unionized ammonia nitrogen concentration was four times

26 (0.05 mg/L) the generally accepted 'safe' threshold while total suspended solids (TSS)

27 exceeded the 'safe' threshold of $25 \mathrm{mg} / \mathrm{L}$ by a factor of $>2.5$. Still, rainbow trout revealed

28 high survival rates of $>99 \%$ and no observable detrimental effects of TSS. Bacterial

29 activity showed a close positive linear correlation with solid load and was almost

30 exclusively explained by solid load for TSS concentration $>10 \mathrm{mg} / \mathrm{L}$. However, bacterial

31 activity had no apparent detrimental effect on fish health or performance. Increased

32 unionized ammonia nitrogen concentrations had no relevant detrimental effect on rainbow

33 trout physiology and performance at concentrations of up to $0.05 \mathrm{mg} / \mathrm{L}$. Furthermore, the

34 absent to minor solid-related effects across a wide range of physiological criteria combined

35 with chronic exposure to unionized ammonia demonstrates that chemical or physical

36 irritants are not problematic in RAS if other water and holding parameters are optimal.

37 These findings suggest a greater than expected tolerance of rainbow trout to chronic TSS-

38 related effects which should result in a revision of water quality threshold criteria for RAS.

39

40 Keywords: Fish health, Water quality, Particle accumulation, Turbidity, Salmonid, Bacterial

41 activity

42 
Highlights:

44 - Study of combined chronic effects of critical solid and unionized ammonia exposure

- Full control of water parameters except turbidity in replicated RAS

- Only minimal effects of $\mathrm{NH}_{3}-\mathrm{N}$ up to $0.05 \mathrm{mg} / \mathrm{L}$ on fish physiology

- No interaction effects between unionized ammonia and suspended solid load

- Close linear correlation of suspended solid load and bacterial activity

51 Aquaculture is the fastest-growing sector in the animal food production industry worldwide and already accounts for more than 44 percent of global total fish production (FAO, 2016). As capture fishery production has remained relatively static since the late 1980 s and the world demand for fish is increasing (FAO, 2016), aquaculture has an important role to play in ensuring a sufficient global fish supply (Naylor et al., 2000). Recirculating aquaculture systems (RAS) are often regarded as an environmentally friendly alternative to open flowthrough or cage-based aquaculture systems (Ayer and Tyedmers, 2009; Klinger and Naylor, 2012; Verdegem et al., 2006), largely due to their efficient water use. However, despite ongoing development, fish production in RASs remains energy- and cost-intensive and its contribution to global production is still small (Badiola et al., 2012; Roque d'Orbcastel et al., 2009). One approach to optimizing the economic output of RASs is to increase stocking densities to reduce costs per unit of fish produced (Martins et al., 2005). However, more fish reared in the same volume of water leads to increased excretion loads per $\mathrm{m}^{3}$ of water. Fish feces are the principal constituent of suspended solids in aquacultural facilities along with uneaten feed, bacterial material from biofilters and microfauna (Chen and Malone, 1991; Noble and Summerfelt, 1996; Summerfelt et al.,

67 1999; Wedemeyer, 1996). Accumulating particles, and especially fine particles, are 
69 Chapman et al., 1987; Chen et al., 1993; Chen and Malone, 1991; Herbert and Merkens, 1961). However, this assertion has been questioned for rainbow trout by recent

71 investigations (Becke et al., 2017, 2018). Nevertheless, intensification of aquacultural production resulting in an increase in suspended solid concentration, will also lead to an increase in dissolved wastes, such as unionized ammonia $\left(\mathrm{NH}_{3}\right)$ (Ip et al., 2001). High unionized ammonia levels have a wide range of detrimental effects on fish, e.g. deterioration of gill structures, and might ultimately lead to mortality (Cameron and Heisler, 1983; Daoust and Ferguson, 1984; Ip et al., 2001; Randall and Tsui, 2002; Smart, 1976; Thurston et al., 1984; Wicks et al., 2002). The common upper safe limit of unionized ammonia-N proposed for salmonid aquaculture is $0.0125 \mathrm{mg} / \mathrm{L}$ (Timmons and Ebeling, 2010). However, there are studies reporting higher tolerance (Daoust and Ferguson, 1984; Meade, 1985). Thus, there is still controversy about the safe threshold for unionized

81 ammonia in aquaculture operations.

A recent factor significantly influencing water quality in aquaculture is a change in feed composition. Fish meal and fish oil are increasingly being substituted by plant alternatives in salmonid diets (Glencross et al., 2007; Ytrestøyl et al., 2015). This is partly due to declining fish stocks and rising prices for fish meal and fish oil (Naylor et al., 2009). This replacement coincidently causes a less dense and more fragile composition of fish feces (Schumann et al., 2018; Unger and Brinker, 2013), considerably increasing fine suspended solids in fish farm waters (Brinker and Friedrich, 2012). Against this background, the present study investigated the sole effect of critical unionized ammonia-N concentrations ( $>0.0125 \mathrm{mg} / \mathrm{L}$ ) as well as interaction effects with suspended solid load in a farm-scale RAS. It was hypothesized that chronic exposure to high unionized ammonia concentrations would cause a reduction of fish wellbeing, while the

93 combined chronic exposure with increased suspended solid load would provoke an 94 interactive impact. Within this context, husbandry waters were set to optimal values except 
95 for the two variables, unionized ammonia and suspended solids, being tested. The exception was bacterial activity which was held at an uncritical level (Pedersen et al., 2017; Rojas-Tirado et al., 2018), with possible covariate influences being controlled by the experimental design.

2 Materials and Methods

2.1. Husbandry

102

The experiment used two replicate RASs, each with 10 tanks (capacity of $330 \mathrm{~L}$, total RAS volume $6 \mathrm{~m}^{3}$ ) (Figure 1), as described by Becke et al. (2018). The study used all-female rainbow trout (Oncorhynchus mykiss, Störk strain) to exclude sex-related effects. Each RAS was stocked with 785 rainbow trout with an average initial weight of $87.2 \pm 8.6 \mathrm{~g}$ (control group) and $87.4 \pm 9.2 \mathrm{~g}$ (treatment group). They were held at maximum stocking densities of $67.8 \pm 3.0 \mathrm{~kg} \mathrm{~m}^{-3}$ (control) and $68.3 \pm 2.6 \mathrm{~kg} \mathrm{~m}^{-3}$ (treatment). The control RAS was operated under regular conditions, while the particle load of the treatment RAS was artificially elevated as described in Becke et al. (2018). Briefly, a mud pump (Wilo-EMU KS $8 \mathrm{ES}$, Dortmund, Germany) was used to pump the backwash water of the drum filter back into the system. In both systems, the drum filter (HDF801-1H, Hydrotech, Vellinge, Sweden) was equipped with a $100 \mu \mathrm{m}$ gauze, so that particles $<100 \mu \mathrm{m}$ accumulate over time.

114 The photoperiod was fixed at 12L:12D with a sigmoidal transition period of $30 \mathrm{~min}$ (Lumilux 115 daylight lamps) with different light intensities of 50,100, 200, 300 and $600 \mathrm{~lx}$ in duplicate 116 per system. However, without any significant effect on the results presented (unpublished 117 data). The fish were fed restrictively according to supplier recommendations with a commercial feed (Biomar EFICO Enviro 921, Aarhus C, Denmark), by hand six days a 119 week (Sunday to Friday) at $2.5 \%$ of body weight at the beginning of the trial, declining to $1201.3 \%$ by the end (maximum feed amount was $2.84 \mathrm{~kg} /$ day per RAS). Bacterial growth was 
controlled with UV irradiation of the system water (Barrier L20, Wallace \& Tiernan,

122 Günzburg, Germany; UV dose: $40 \mathrm{~mJ} / \mathrm{cm}^{2}$ flow volume: $6600 \mathrm{~L} / \mathrm{h}$, lamp wattage: $80 \mathrm{~W}$, measurement range UV sensor: $200 \mathrm{~W} / \mathrm{m}^{2}$ ). Fish (average weight approx. $15 \mathrm{~g}$ ) were put

124 into the two RASs three months before the beginning of the experiment to ensure 125 acclimatization.

\subsection{Water parameters}

128 The experiment was subdivided into three phases (Figure 2): in phase 1 (week $1-5$ ), water parameters in both RASs were kept at levels known to preclude negative impacts on fish health or performance (Table 1). In the treatment RAS, however, the total suspended solid concentration was increased to over $35 \mathrm{mg} / \mathrm{L}$ and was subsequently held constantly above this value. The control RAS operated under commercial conditions at around 5 $\mathrm{mg} / \mathrm{L}$ throughout the experiment. In phase 2 (week $6-10$ ), ammonium concentration was artificially elevated in both RASs by adding ammonium chloride (A7012,9025; AppliChem,

Darmstadt, Germany). Additionally, biofilter efficiency in both RASs was reduced by halving the volume of carrier material (originally designed for $4.5 \mathrm{~kg}$ feed/day) to attain higher $\mathrm{NH}_{4}-\mathrm{N}$ concentrations. Ammonium nitrogen concentration was measured in both RASs every 60 minutes using an automat (AMTAX SC, Hach, Germany). In addition, pH was increased from 7.5 to around 8 in both RASs to increase the proportion of unionized ammonia nitrogen $\left(\mathrm{NH}_{3}-\mathrm{N}\right)$ to approximately $0.0125 \mathrm{mg} / \mathrm{L}$ (Figure 3). The increase in $\mathrm{pH}$ was achieved by adding sodium hydrogen carbonate, dissolved in water, using a peristaltic pump (Concept 420i, Saier Dosiertechnik, Germany). The pH was constantly monitored using OxyGuard pH-probes (Farum, Denmark). The concentration of unionized ammonia-

$144 \mathrm{~N}$ was calculated based on actual $\mathrm{pH}$ and temperature according to Emerson et al. (1975).

145 In phase 3 (week 11 - 13), the concentration of unionized ammonia-N was further 146 increased to an average of approximately $0.025 \mathrm{mg} / \mathrm{L}$ (Figure 3). 
$147 \mathrm{NH}_{4}-\mathrm{N}, \mathrm{NO}_{2}-\mathrm{N}$ and $\mathrm{NO}_{3}-\mathrm{N}$ were chemically determined three times per week throughout 148 the experiment with analysis kits (LCK 304: $0.2-2.5 \mathrm{mg} / \mathrm{L} ; \mathrm{LCK} 341: 0,05-2 \mathrm{mg} / \mathrm{L}$; and 149 LCK 339: 1 - 6 mg/L, Hach, Germany, respectively), using water from the connecting tube 150 from the fish tanks of each RAS. Oxygen concentration (using Oxygen Probes, OxyGuard, 151 Farum, Denmark) and temperature (using Temperature Probes, Oxyguard, Farum, 152 Denmark) were monitored continuously at the outlets of two fish tanks in each system.

153 Carbon dioxide concentrations were determined two times per week in the fish tanks using 154 a portable dissolved $\mathrm{CO}_{2}$ analyzer (OxyGuard $\mathrm{CO}_{2}$ Portable, OxyGuard, Farum, 155 Denmark). Turbidity was determined three times per week in parallel with the 156 determination of total suspended solids using a turbidity meter (PCE-TUM 20, PCE 157 Instruments, Germany).

2.3. Analysis of suspended solids

\subsubsection{Total suspended solids}

161 The concentration of total suspended solids was determined three times per week in 162 duplicate for each system according to method 2540 D of the American Public Health 163 Association (APHA, 1998), with the exception that $0.45 \mu \mathrm{m}$ cellulose-acetate filters 164 (diameter: 50mm, 11106-50-N, Sartorius AG, Göttingen, Germany) were used instead of glass-fiber filters due to the smaller and better defined pore sizes. Filters were prepared as described by Becke et al. (2018). Water samples were collected using a tube at a water depth of ca. $30 \mathrm{~cm}$ from five tanks in each system, then duplicate samples were pooled to create a representative sample for each system. Samples were collected in the early morning before feeding, in order to represent the daily minimum solid loads (best case scenario). To determine the within-day fluctuations and maximum values, measurements were performed every two hours on one day in week 12. 
174 For particle size measurement, water samples were collected as described above. Particle sizes were determined according to Brinker et al. (2005) using a non-invasive laser particle sizer (GALAI:CIS-1, GALAI Productions Ltd. Midgal Haemak, Israel) equipped with a flow controller (GALAI:LFC-100) and a flowthrough cell (GALAI:GM-7). The measurements were performed in quadruplicate for each system in week 12 of experimental operation.

\subsection{Fish performance}

181 The specific growth rate (SGR) was calculated from mean weights recorded at the 182 beginning and the end of the experiment by using the following formula:

$183 S G R\left(\% d^{-1}\right)=(\operatorname{In}($ mean final weight $)-\ln ($ mean initial weight $)) /(t($ final day $)-t($ initial day $)) \times 100$;

184 where $t$ is time (days).

185 The feed conversion ratio (FCR) was calculated as:

$186 \quad F C R=$ Feed $(\mathrm{kg}) /$ Weight gain $(\mathrm{kg})$

187 The thermal growth coefficient (TGC) was calculated according to Jobling (2003):

$188 T G C=\left(W_{t}^{1 / 3}-W_{0}^{1 / 3}\right) \times(\Sigma T)^{-1} \times 1000$

189 where $W_{t}$ and $W_{0}$ are the final and initial weights $(g)$, respectively and $\sum T$ is sum day190 degrees Celsius (Cho, 1992; Iwama and Tautz, 1981).

\subsection{Sampling protocol}

193 Fish were sampled at the beginning, in week 5, in week 10 and in week 13 of the study. 194 Fish were fasted $24 \mathrm{~h}$ prior to each sampling. Two fish from each tank per system $(\mathrm{n}=20)$ were caught and anaesthetized using clove oil (concentration: $0.1 \mathrm{~mL} / \mathrm{L}$, exposure time: ca. $60 \mathrm{~s}$ ). Directly following anesthesia, wet weight (to the nearest $0.1 \mathrm{~g}$ ) and total length (measured from the tip of the mouth to the end of the tail fin; to the nearest $0.1 \mathrm{~cm}$ ) of each fish were measured and blood samples were taken from the caudal blood vessels and 
transferred to tubes containing lithium heparin $(25 \mathrm{IU} / \mathrm{mL}$ blood, Sarstedt, Nümbrecht, 200 Germany). Subsequently, fish were killed and samples of gill tissue were collected for 201 histological examination.

2.6. Health parameters

2.6.1. Gill histology

205 Gill tissue was prepared and examined as described by Becke et al. (2018). Briefly, 206 observed changes were ranked rising in pathology from 0 (no change) to 3 (severe 207 change) including sub-steps 1 (minor change) and 2 (moderate change). For each section, 2085 images showing $6-7$ secondary gill lamellae were inspected at a magnification of $200 \times$ 209 using a photomicroscope (Zeiss, Oberkochen, Germany). Branchial epithelium thickness $210(\mu \mathrm{m})$ was measured at 10 locations in each image and a mean value was calculated. The 211 number of goblet cells was counted per secondary lamella. The gills of 20 rainbow trout 212 from each RAS were investigated at each sampling point.

\section{$214 \quad$ 2.6.2. Fin condition}

215 Fin erosion as an indicator of fish welfare was assessed according to Person-Le Ruyet et al. (2007), and the fin index was determined according to Kindschi (1987), as follows:

217 Fin index $=(\text { fin length/total length })^{*} 100$

\subsubsection{Hematology}

220 Hematological parameters (differential leukocyte count, hematocrit, leukocrit, hemoglobin 221 concentration, total red and white blood cell counts) were determined as described by Becke et al. (2018). Glucose concentration was determined using a common glucose 223 measuring device (ACCU-CHEK Aviva, Roche, Mannheim, Germany) as it has been 
224 shown that devices for measuring human glucose level are also suitable for use with fish

225 blood (Bartoňková et al., 2017; Eames et al., 2010).

2.7. Bacterial assay

\subsubsection{Bacterial load}

229 Analysis of bacterial load of rainbow trout was conducted at the termination of the study 230 (20 rainbow trout per RAS) by the fish health service at a governmental veterinary institute, 231 the Staatliches Tierärztliches Untersuchungsamt (STUA) Aulendorf, Germany as 232 described in Becke et al. (2018). Briefly, the number of colony forming units was assessed 233 on skin and spleen and ranked as no, sporadic, slight, moderate or severe bacterial load. 234 Bacterial species were then determined by using bacteriological standard methods and 235 confirmed by MALDI-TOF MS (Lay, 2001).

\subsubsection{Bacterial activity in the water}

238 Bacterial activity in the fish tanks was assessed using a patented method called 239 BactiQuant $^{\circledR}$ (Mycometer A/S, Copenhagen, Denmark), which is an indirect measure of 240 microbial enzyme activity. Reproducibility and repeatability of the method has been 241 documented in a verification report by the United States Environmental Protection Agency 242 (U.S.-EPA, 2011). Briefly, a $10 \mathrm{~mL}$ water sample was filtered through a Millipore $0.22 \mu \mathrm{m}$ 243 closed filter unit (PES express). The filter was then incubated with a fluorogenic enzyme 244 substrate for $15 \mathrm{~min}$. The synthetic fluorescent enzyme-substrate is hydrolyzed by 245 microbial enzymes in the water sample and the amount of released fluorophores was 246 quantified with a fluorometer (Mycometer A/S, Copenhagen, Denmark). The results were 247 expressed in standardized Bactiquant ${ }^{\circledR}$ values (BQV; hereafter termed bacterial activity). 248 Measurements were always performed in duplicate. During the first three weeks, bacterial 249 activity was measured every second day to gain a better overview of the development until 
250 the particle concentration exceeded $35 \mathrm{mg} / \mathrm{L}$ in the treatment RAS. From week 4 onwards, 251 bacterial activity was measured twice a week.

2.8. Data analysis

254 Data were checked for homoscedasticity using Levene's test (Levene, 1960) and for normality using normal quantile plots. If normal distribution and homoscedasticity tests were passed, treatment effects were tested by $t$-tests, otherwise Wilcoxon tests were employed (Sokal and Rohlf, 2003). For analysis of bacterial activity, branchial epithelium thickness and number of goblet cells per secondary lamella a linear parametric model was applied (Supplement 1).

260 Fin erosion and gill histology parameters (thickening of epithelial cells, cellular edema, cell 261 infiltration, tip thickening, detachment of the epithelium, telangiectasia and lamellar fusion) 262 were tested using a logistic regression on ordinal data. The method of least squares was 263 used to analyze the relation between TSS concentration and turbidity. Bacterial load data 264 of the gills was analyzed using Fisher's exact test. A generalized linear model (GLM) was 265 used to analyze fin index and hematological parameters.

266 The coefficient of variation $\left(\mathrm{C}_{\mathrm{V}}\right)$ as a unit for the relative standard deviation was calculated 267 in terms of bacterial activity as follows:

$C_{V}(\%)=($ standard deviation $(\sigma) /$ arithmetic mean $(\bar{x})) \times 100$

All data analyses were performed with JMP Pro (SAS Institute Inc.) version 13.2.1. (64-bit) Differences between treatment groups were considered to be significant at $P<0.05$.

2723 Results

\subsection{Water parameters}

274 Water temperature differed significantly $(P<0.001)$ between control and treatment RAS, 275 although the absolute difference was small and below $0.6{ }^{\circ} \mathrm{C}$ (Table 1). In week 11 to 13 , 
$276 \mathrm{NO}_{2}-\mathrm{N}$ concentration was approximately $0.15 \mathrm{mg} / \mathrm{L}$ higher in the control RAS and differed 277 significantly $(P<0.05)$ between RAS systems, but not in phase one and two of the experiment $(P>0.05)$. Water consumption was significantly higher $(P<0.05)$ in the control system in week 1 to 5 (approx. 40 L/day) and in week 6 to 10 (approx. 22 L/day) than in the treatment because the backwash water of the drum filter was reinjected into the treatment system. From week 11 to 13 no significant difference $(P>0.05)$ was found between systems due to adjusting the water consumption in the treatment system. However, magnitudes of differences were minimal and were thus deemed biologically not relevant. Turbidity differed significantly $(P<0.001)$ by up to 15 NTU (Nephelometric Turbidity Units) between control and treatment RAS at individual sampling time points (Table 1) as related to different suspended solid load. $\mathrm{NH}_{4}-\mathrm{N}$ concentrations, $\mathrm{pH}, \mathrm{O}_{2}$ concentration and $\mathrm{NO}_{3}-\mathrm{N}$ concentration did not differ significantly $(P>0.05)$ between control and treatment system. $\mathrm{NH}_{4}-\mathrm{N}$ concentrations were increased both in the control and treatment RAS after week 5 and week 10 with concentrations peaks of up to $2.5 \mathrm{mg} / \mathrm{L}$ 290 (control) and $2.3 \mathrm{mg} / \mathrm{L}$ (treatment) respectively, but without significant differences $(P>$ $0.05)$ between systems. Unionized ammonia-N concentrations were also increased after week 5 from 0.005 to $0.012 \mathrm{mg} / \mathrm{L}$ and further to over $0.02 \mathrm{mg} / \mathrm{L}$ after week 10 (Figure 3), 293 however, without significant differences $(P>0.05)$. Overall, with the exception of $\mathrm{NH}_{4}{ }^{-}$ $294 \mathrm{~N} / \mathrm{NH}_{3}-\mathrm{N}$ and suspended solid load, all water parameters remained within physiological 295 optimal range for rainbow trout (Timmons and Ebeling 2010).

297 3.2. Suspended solids analysis

$298 \quad$ 3.2.1 Total suspended solids

299 Total suspended solid (TSS) concentration differed significantly $(P<0.0001)$ between 300 control and treatment RAS with an average concentration of $4.5 \mathrm{mg} / \mathrm{L}$ in the control and $30135.2 \mathrm{mg} / \mathrm{L}$ in the treatment system (Figure $4 \mathrm{~A}$ ). From week 3 , the TSS concentration in 
the treatment system exceeded $30 \mathrm{mg} / \mathrm{L}$ and remained at an average of $40.5 \mathrm{mg} / \mathrm{L}$.

303 Furthermore, the difference in TSS concentration between control and treatment RAS was

304 never less than $23.1 \mathrm{mg} / \mathrm{L}$. Figure $4 \mathrm{~B}$ shows the within-day variation of the total

305 suspended solids concentration in the control and treatment RAS in week 12 of the

306 experiment with minimum values in the morning at 7:00 a.m. The highest TSS

307 concentration on that day was $65.8 \mathrm{mg} / \mathrm{L}$ in the treatment RAS while it was $14.1 \mathrm{mg} / \mathrm{L}$ in

308 the control RAS.

\subsubsection{Particle size distribution}

311 At week 12, the total number of particles per liter in the treatment RAS was on average

312 more than double that of the control. The average suspended particle load was $17.1 \pm 2.1$

$313 \mathrm{mg}$ dry weight/L in the control and $47.4 \pm 2.7 \mathrm{mg}$ dry weight/L in the treatment system. For

314 each particle size class, the absolute frequencies differed significantly $(P<0.001)$ between

315 control and treatment RAS (Figure 5). Overall, a high accumulation of fine particles

316 occurred in both the control and the treatment RAS, with $98.6 \%$ and $98.3 \%$ of all particles

317 respectively smaller than $15 \mu \mathrm{m}$, however, with higher quantities in the treatment RAS.

\subsection{Fish performance}

In contrast to the expectations based on recommended threshold values, fish performed

321 very well in both systems. A slight difference in feeding behavior was observed between

322 fish in the two systems with a less aggressive and calmer feeding behavior in the

323 treatment RAS. Overall, no significant differences $(P>0.05)$ were apparent for final

324 weight, survival rate, FCR, SGR and TGC between rainbow trout of the control and

325 treatment RAS (Table 2). 
329 No severe histological changes in gill structures were observed during the investigation.

330 Cases of cellular edema, tip-thickening of secondary lamellae, telangiectasia, thickening of 331 epithelial cells, cell infiltration, lamellar fusion, merging of secondary lamellae and 332 detachment of the epithelium were only minor or moderate (Supplement 2). In terms of 333 cellular edema, all factors were significantly altered by treatment $(P<0.05)$, but magnitude 334 of differences was small $(0-15 \%)$ and the observed histological change was only rated 335 as minor. The increased TSS concentration did not have any significant effect on all further 336 investigated histological parameters $(P>0.05)$. However, the increased unionized ammonia concentration $(P<0.05)$ and the interaction of unionized ammonia concentration and day of sampling $(P<0.05)$ led to a significantly more frequent occurrence of cell infiltrations and tip thickening of secondary lamellae. All other histological parameters were not significantly affected by the increased unionized ammonia concentration $(P>0.05)$.

341 Furthermore, no significant interaction of increased unionized ammonia concentration and 342 increased suspended solid load $(P>0.05)$ were found for any of the investigated 343 histological parameters.

344 Regarding thickness of branchial epithelium and number of goblet cells per secondary 345 lamella (Supplement 3), no significant effects $(P>0.05)$ of increased unionized ammonia 346 or suspended solid load were apparent at all.

\subsubsection{Fin condition}

349 Neither total suspended solid concentration $(P>0.05)$ or unionized ammonia $(P>0.05)$ 350 had a significant effect on fish welfare measured by fin erosion in the control and treatment 351 RAS (Supplement 4). Furthermore, no interaction effect of increased unionized ammonia 352 concentrations and suspended solid load was apparent $(P>0.05)$. 
353 The increased unionized ammonia concentrations caused a significantly lower fin index

$354(P<0.05)$ for the dorsal fin (Supplement 5). However, fin indices of the left and right 355 pectoral fin were not affected $(P>0.05)$. Increased suspended solid load had no 356 significant effect $(P>0.05)$ on any fin index. Furthermore, the elevated unionized 357 ammonia concentrations did not significantly affect the impact of suspended solid load $358 \quad(P>0.05)$ on fin indices.

\subsubsection{Hematology}

361 Overall, all hematological parameters (Table 3) were approximately within the range 362 previously reported for salmonids (McCarthy et al., 1973, 1975; Pund, 1998; Rehulka et 363 al., 2004). However, hematocrit was significantly decreased $(P<0.05)$ both with 364 increasing TSS concentration and increasing body length, whereas hematocrit significantly 365 increased $(P<0.05)$ over time. Thus, the MCV value was also significantly lower $(P<$ $3660.01)$ and the $\mathrm{MCHC}$ value significantly higher $(P<0.01)$ with increasing TSS 367 concentrations. The interaction of TSS concentration and unionized ammonia 368 concentration revealed a significant effect $(P<0.05)$ on $\mathrm{MCHC}$ values. The number of 369 thrombocytes was significantly elevated $(P<0.05)$ with increasing unionized ammonia 370 concentration and the hemoglobin concentration significantly increased $(P<0.05)$ over 371 time. All the other parameters (glucose concentration, number of erythrocytes, $\mathrm{MCH}$, 372 number of leukocytes, leukocrit and the proportions of lymphocytes, granulocytes and 373 monocytes) were not significantly affected $(P>0.05)$ by suspended solid load, unionized 374 ammonia concentration or the interaction of both parameters. 
378 Overall, no critical bacterial load was detected in the control or treatment RAS. Bacterial 379 load of the gills differed significantly between fish of the control and treatment RAS in 380 terms of direct detection $(P<0.01)$ with $45 \%$ and $10 \%$ of the fish gills showing no 381 bacterial load in the control and treatment RAS respectively (Figure 6). In contrast, $90 \%$ of 382 the fish gills in the treatment RAS and only $40 \%$ of the fish gills in the control RAS 383 revealed slight to moderate bacterial load. However, no significant difference appeared in 384 terms of cultivation $(P>0.05)$. The bacterial load of the spleen was significantly higher $(P$ $385<0.0001)$ for rainbow trout in the suspended solids enriched RAS. In the control RAS, 95 $\%$ of the spleens revealed no to sporadic bacterial load, whereas in the treatment system $75 \%$ of the spleens revealed slight to moderate bacterial load. The examination of the skin revealed no bacteria or ectoparasites in either RAS. The fish pathogenic bacteria Flavobacterium columnare was detected on two rainbow trout from the control RAS and on four rainbow trout from the treatment RAS by direct detection. The cultivation of gill smears proved the occurrence of Aeromonas sobria for three fish in the treatment RAS, but not in the control RAS.

\subsubsection{Bacterial activity}

395 Bacterial activity ranged between $0.12 \times 10^{5}$ and $0.47 \times 10^{5}$ in the control RAS $\left(\mathrm{C}_{\mathrm{v}}=18.0 \%\right)$ and between $0.33 \times 10^{5}$ and $3.42 \times 10^{5}$ in the treatment RAS $\left(C_{v}=18.3 \%\right)$ (Figure 7$)$. Bacterial activity was only significantly affected $(P<0.0001)$ by the total suspended solid concentration. With increasing particle load in the treatment RAS, bacterial activity increased from about $0.3 \times 10^{5}$ to over $2.6 \times 10^{5}$ during the first three weeks. In contrast, 400 bacterial activity in the control RAS remained roughly static between $0.2 \times 10^{5}$ and $0.3 \times 10^{5}$ 401 during this time. Unionized ammonia-N concentration had no significant effect $(P>0.05)$ 402 on bacterial activity in either RAS. Bacterial activity measured on one representative day in 403 week 8 showed diurnal variations from $0.2 \times 10^{5}$ to $0.4 \times 10^{5}$ in the control RAS and from 
$4042.3 \times 10^{5}$ to $3.7 \times 10^{5}$ in the treatment RAS respectively. Overall, there was a significant 405 positive linear correlation between TSS concentration and bacterial activity $\left(P<0.0001, r^{2}\right.$ $406=0.98$; Figure 8). However, the certainty measure of the linear correlation of bacterial 407 activity with TSS was very low in the control RAS $\left(r^{2}=0.10\right)$ while it was high in the 408 treatment RAS $\left(r^{2}=0.94\right)$.

4104 Discussion

411 The experiment effectively decoupled the effects of chronic suspended solid load and 412 elevated unionized ammonia concentrations from other relevant water quality parameters.

413 This allowed an investigation of the sole effects of both increased unionized ammonia 414 concentrations and suspended solid load on rainbow trout as well as their combined 415 effects at a farm-scale.

416 Recent investigations (Becke et al., 2017, 2018) have shown that even massive 417 accumulation of fine solids alone caused no detrimental effects on rainbow trout in RAS.

418 These results were corroborated by the present findings which did not reveal relevant 419 detrimental effects of increased suspended solid concentrations on fish at concentrations 420 of up to almost $70 \mathrm{mg} / \mathrm{L}$. Gills are of delicate structure and therefore highly sensitive to 421 physical impact (Evans, 2005; Morgan and Tovell, 1973), so the absence of any 422 histological alteration associated with suspended solid load is of particular note. This is in 423 line with Goldes et al. (1988) who also observed no branchial pathology in rainbow trout 424 even when exposed to up to $1017 \mathrm{mg} / \mathrm{L}$ of suspended clay kaolin. Thus, the assumption 425 that suspended solids alone are not a key issue affecting fish welfare in RAS is further 426 strengthened.

427 However, the increased particle load caused indirect effects. It led to increased turbidity 428 which suppressed feeding behavior of fish in the treatment RAS as previously described 429 (Barrett et al., 1992; Becke et al., 2017, 2018; Utne-Palm, 2002). This altered feed uptake 
can potentially lead to a loss of feed in commercial settings using automatic feeders. To

431 preclude this potentially disturbing effect, fish in this study were hand fed which secured

432 the uptake of all feed pellets.

433 Furthermore, the increased suspended solid load induced a substantial increased bacterial

434 load. Such a finding was expected (Becke et al., 2018) as an increased number of

435 particles in the treatment RAS promotes bacterial growth by providing a larger surface area for bacterial colonization and food-substrate. Bacterial activity levels found in this study have been observed in other recent studies rearing rainbow trout in intensive RAS (Pedersen et al., 2017; Rojas-Tirado et al., 2018). Especially remarkable is the close linear correlation between bacterial activity and TSS, which is however quite variable at low TSS

$440 \quad(<5 \mathrm{mg} / \mathrm{L})$, but nearly exclusively determined by TSS at high TSS loads. This novel 441 outcome is of high relevance for systems with need for bacterial control. However, the 442 physiological parameters investigated here did not reveal any evidence for bacterially 443 mediated physiological stress response in the control or in the treatment systems. This 444 was confirmed by the independent veterinary inspection of the rainbow trout which did not 445 reveal any relevant pathological bacterial infestation. In contrast, Redding et al. (1987) 446 observed a reduced tolerance to subsequent infection with Vibrio anguillarum for yearling 447 steelhead when exposed to high concentrations of suspended topsoil. In the present 448 study, however, no bacterial diseases occurred despite very high bacterial and suspended 449 solid load in the treatment RAS. However, under different conditions, the interaction of 450 suspended solids and bacterial occurrence might impair fish health and need to be 451 controlled (Herbert and Merkens, 1961; Qualls et al., 1983).

452 Increased particle concentrations, e.g. due to increased stocking densities in RAS, are 453 often accompanied by a decrease in water quality because of leaching of harmful 454 substances or particle-mediated growth of heterotrophic bacteria (Chen et al., 2003; Ling 455 and Chen, 2005). To simulate this phenomenon on a farm-scale, the concentration of 
unionized ammonia- $\mathrm{N}$ was increased to levels which exceeded the common upper safe

457 limit of $0.0125 \mathrm{mg} / \mathrm{L}$ proposed for salmonid aquaculture (Timmons and Ebeling, 2010). It

was hypothesized that the chronic exposure to increased unionized ammonia

concentrations would result in a deterioration of physiology and performance of rainbow trout. However, contrary to the hypotheses and praxis as well as academic opinion (Smith and Piper, 1975; Thurston et al., 1984; Timmons and Ebeling, 2010), rainbow trout exposed to chronic unionized ammonia- $\mathrm{N}$ concentrations of more than four times the critical threshold did not reveal deteriorated performance in our study. Fish in both systems showed very good performance with nearly $100 \%$ survival. Only minor physiological effects of increased unionized ammonia concentration on gill structure were observed. Nonetheless, the observed alterations of gill structures were only slight to moderate and only two (cell infiltrations, tip thickening of secondary lamellae) out of seven parameters were significantly affected by the increased unionized ammonia load. Thus, these results suggest that the rainbow trout can cope well with the given unionized ammonia concentrations. The common upper safe limit of unionized ammonia- $\mathrm{N}$ of $0.0125 \mathrm{mg} / \mathrm{L}$ 471 proposed for salmonid aquaculture is based on the findings of Smith and Piper (1975). 472 However, other authors, such as Meade (1985), Daoust and Ferguson (1984) (laboratory experiment) and Kolarevic et al. (2013) (commercial scale) previously questioned the 474 proposed unionized ammonia limit. Nevertheless, the value of $0.0125 \mathrm{mg} / \mathrm{L}$ has been 475 echoed widely since then and established in aquaculture textbooks (e.g. Timmons and 476 Ebeling, 2010). However, it has to be noted that oxygen concentration was low (around 6 $477 \mathrm{mg} / \mathrm{L}$ ) in the Smith and Piper (1975) study. According to Lloyd (1961) and Brown (1968), unionized ammonia toxicity increases with decreasing oxygen levels. Thus, the interaction 479 of low oxygen with high unionized ammonia concentration in the study of Smith and Piper 480 (1975) might be causative for the pathological changes in the gills of rainbow trout. During 481 the present study, however, the system water was saturated with oxygen during the whole 
investigation period. Thus, in relation to oxygen, unionized ammonia toxicity was kept to a 483 minimum which might explain the observed low impact. Overall, the presumption for a 484 higher tolerance level of rainbow trout to unionized ammonia was confirmed by the results here showing no relevant effects on fish physiology at the given unionized ammonia concentrations.

487 In this context, the stress-modulated effects are important given that stressed fish are 488 more vulnerable to external unionized ammonia toxicity than unstressed fish (Randall and 489 Tsui, 2002). Thus, the low impact of elevated unionized ammonia concentrations while 490 concomitantly exposed to high fine particle loads render the solid exposure harmless as 491 well.

492 Regarding the impact of unionized ammonia on fin condition, only the dorsal fin was 493 negatively affected. As fin condition is frequently consulted to assess fish welfare (Ellis, 494 2002; Ellis et al., 2008; Turnbull et al., 2005), the almost complete absence of any fin 495 deterioration here is remarkable and indicates the very low impact of the unionized 496 ammonia and solid stressors. Abbott and Dill (1985) assumed that aggressive interaction 497 is the major cause of fin damage in hatchery salmonids. In the present study, fin condition 498 of rainbow trout was marginally better in the solid enriched RAS than in the control RAS. 499 This might be attributable to the calmer behavior and reduced social interaction of fish due 500 to the turbid conditions in the treatment RAS (Bash et al., 2001).

501 The analysis of hematological parameters revealed significant effects for individual 502 parameters both in terms of suspended solids and unionized ammonia. However, taking all 503 hematological parameters together, there was no indication of pathological effects. Knoph 504 and Thorud (1996) also did not observe any negative effect of unionized ammonia-N up to $5050.112 \mathrm{mg} / \mathrm{L}$ on hematological parameters (hematocrit, RBC count) of Atlantic salmon. 506 Furthermore, Becke et al. $(2017,2018)$ observed no significant effects of suspended solid 507 load up to $70 \mathrm{mg} / \mathrm{L}$ on hematological parameters. 
508 As a consequence of the massive accumulation of fine particles in the treatment RAS and

509 the additionally increased unionized ammonia concentration in both systems, it was

510 hypothesized that a multiplicative effect of these two parameters would occur in the

511 treatment RAS, resulting in significant consequences on trout physiology. However, none

512 of the investigated physiology parameters revealed any relevant multiplicative effects of

513 particle and unionized ammonia load. In contrast to our hypothesis, no synergistic impact

514 of increased unionized ammonia concentrations and suspended solid load on fish

515 physiology was found. These results indicate that the commonly used upper safe limits of

$5160.0125 \mathrm{mg} / \mathrm{L}$ for unionized ammonia-N and $25 \mathrm{mg} / \mathrm{L}$ for total suspended solids do not

517 represent the actual critical limits for salmonid aquaculture. Fish have evolved

518 mechanisms to counteract high unionized ammonia environments, as shown for rainbow

519 trout (Randall and Tsui, 2002; Wicks and Randall, 2002). This suggests that rainbow trout

520 have probably developed an improved tolerance to poor water quality in the course of

521 artificial selection for aquaculture. Positive effects of moderately elevated ammonia

522 concentrations have even been observed for rainbow trout when fed to satiation (Linton et

523 al., 1997, 1999; Wood, 2004). Thus, more research that keeps track of breeding

524 developments is needed to clarify the exact effects of water parameters on rainbow trout

525 and fish in general both in aquacultural production and natural conditions. It might be that

526 the upper safe limits of certain water quality parameters currently used in aquacultural

527 production no longer correspond to the present genetic makeup of fish and that they

528 should be revised.

5305 Conclusions

531 The results from this study provide a fully controlled insight into the combined effects of 532 particle accumulation and unionized ammonia load on physiology of rainbow trout in RAS 533 on a farm-scale. Against expectations and widespread opinion, the solid fraction of the 
534 experimental system, comprising almost exclusively fine particles at concentrations

535 distinctly above values normally reached in aquacultural production, failed to provoke

536 detrimental effects on physiology and performance of rainbow trout. The same holds for

537 unionized ammonia and the combination of both.

538 The results therefore indicate with respect to suspended solids and unionized ammonia

539 that increasing fish densities to improve the economic performance of RAS beyond current

540 limits of suspended solids and unionized ammonia is feasible, if accompanying water

541 parameters are optimal.

543 Thus, the main conclusions are:

544 - Bacterial activity was strongly affected by increased TSS concentrations, but without detrimental effects on fish physiology

- increased unionized ammonia-N concentrations up to $0.05 \mathrm{mg} / \mathrm{L}$ caused only minor

Acknowledgements

554 We thank Helga Bentele and HP Billmann for their excellent technical assistance, 555 especially with fish husbandry and system maintenance. We also thank the state 556 veterinary institute of Aulendorf for the bacteriological examination of the fish. We also 557 acknowledge the scientific language editing by Erica Bower as well as the valuable input of 558 three anonymous reviewers. This research was funded by the Deutsche Bundesstiftung Umwelt (Az 30996). 
561

562

563

564

565

566

567

568

569

570

571

572

573

574

575

576

577

578

579

580

581

582

583

584

585

586

587

588

589

590

591

592

593

594

595

596

597

598

599

600

601

602

603

604

605

606

607

608

609

Abbott, J.C., Dill, L.M., 1985. Patterns of aggressive attack in juvenile steelhead trout (Salmo gairdneri). Can. J. Fish. Aquat. Sci. 42, 1702-1706.

Ayer, N.W., Tyedmers, P.H., 2009. Assessing alternative aquaculture technologies: life cycle assessment of salmonid culture systems in Canada. J. Clean. Prod. 17, 362373. https://doi.org/10.1016/j.jclepro.2008.08.002

Badiola, M., Mendiola, D., Bostock, J., 2012. Recirculating Aquaculture Systems (RAS) analysis: Main issues on management and future challenges. Aquac. Eng. 51, 2635. https://doi.org/10.1016/j.aquaeng.2012.07.004

Barrett, J.C., Grossman, G.D., Rosenfeld, J., 1992. Turbidity-Induced Changes in Reactive Distance of Rainbow Trout. Trans. Am. Fish. Soc. 121, 437-443. https://doi.org/10.1577/1548-8659(1992)121<0437:TIC IRD>2.3.CO;2

Bartoňková, J., Hyršl, P., Vojtek, L., 2017. Glucose determination in fish plasma by two different moderate methods. Acta Vet. Brno 85, 349-353.

Bash, J., Berman, C.H., Bolton, S., 2001. Effects of turbidity and suspended solids on salmonids. University of Washington Water Center.

Becke, C., Schumann, M., Steinhagen, D., Geist, J., Brinker, A., 2018. Physiological consequences of chronic exposure of rainbow trout (Oncorhynchus mykiss) to suspended solid load in recirculating aquaculture systems. Aquaculture 484, 228241. https://doi.org/10.1016/j.aquaculture.2017.11.030

Becke, C., Steinhagen, D., Schumann, M., Brinker, A., 2017. Physiological consequences for rainbow trout (Oncorhynchus mykiss) of short-term exposure to increased suspended solid load. Workshop Recirc. Aquac. Syst. III 78, 63-74. https://doi.org/10.1016/j.aquaeng.2016.11.001

Bilotta, G.S., Brazier, R.E., 2008. Understanding the influence of suspended solids on water quality and aquatic biota. Water Res. 42, 2849-2861. https://doi.org/10.1016/j.watres.2008.03.018

Brinker, A., Friedrich, C., 2012. Fish meal replacement by plant protein substitution and guar gum addition in trout feed. Part ll: effects on faeces stability and rheology. Biorheology 49, 27-48.

Brinker, A., Schröder, H.G., Rösch, R., 2005. A high-resolution technique to size suspended solids in flow-through fish farms. Aquac. Eng. 32, 325-341. https://doi.org/10.1016/j.aquaeng.2004.07.002

Brown, V.M., 1968. The calculation of the acute toxicity of mixtures of poisons to rainbow trout. Water Res. 2, 723-733.

Cameron, J.N., Heisler, N., 1983. Studies of ammonia in the rainbow trout: physicochemical parameters, acid-base behaviour and respiratory clearance. J. Exp. Biol. 105, 107-125.

Chapman, P.M., Popham, J.D., Griffin, J., Leslie, D., Michaelson, J., 1987. Differentiation of physical from chemical toxicity in solid waste fish bioassays. Water. Air. Soil Pollut. 33, 295-308.

Chen, S., Malone, R.F., 1991. Suspended solids control in recirculating aquacultural systems, in: Engineering Aspects of Intensive Aquaculture, Proceedings from the Aquaculture Symposium. Ithaca, NY, pp. 170-186.

Chen, S., Timmons, M.B., Aneshansley, D.J., Bisogni, J.J., 1993. Suspended solids characteristics from recirculating aquacultural systems and design implications. Aquaculture 112, 143-155. https://doi.org/10.1016/0044-8486(93)90440-A

Chen, Y.-S., Beveridge, M.C.M., Telfer, T.C., Roy, W.J., 2003. Nutrient leaching and settling rate characteristics of the faeces of Atlantic salmon (Salmo salar L.) and the implications for modelling of solid waste dispersion. J. Appl. Ichthyol. 19, 114-117. 
610

611

612

613

614

615

616

617

618

619

620

621

622

623

624

625

626

627

628

629

630

631

632

633

634

635

636

637

638

639

640

641

642

643

644

645

646

647

648

649

650

651

652

653

654

655

656

657

658

659

Cho, C.Y., 1992. Feeding systems for rainbow trout and other salmonids with reference to current estimates of energy and protein requirements. Aquaculture 100, 107-123.

Daoust, P.-Y., Ferguson, H.W., 1984. The pathology of chronic ammonia toxicity in rainbow trout, Salmo gairdneri Richardson. J. Fish Dis. 7, 199-205.

Eames, S.C., Philipson, L.H., Prince, V.E., Kinkel, M.D., 2010. Blood sugar measurement in zebrafish reveals dynamics of glucose homeostasis. Zebrafish 7, 205-213.

Ellis, T., 2002. The relationships between stocking density and welfare in farmed rainbow trout. J. Fish Biol. 61, 493-531. https://doi.org/10.1006/ffbi.2002.2057

Ellis, T., Oidtmann, B., St-Hilaire, S., Turnbull, J., North, B., Maclntyre, C., Nikolaidis, J., Hoyle, I., Kestin, S., Knowles, T., 2008. Fin erosion in farmed fish, in: Fish Welfare. Blackwell Publishing, Oxford, pp. 121-149.

Emerson, K., Russo, R.C., Lund, R.E., Thurston, R.V., 1975. Aqueous ammonia equilibrium calculations: effect of $\mathrm{pH}$ and temperature. J. Fish. Board Can. 32, 2379-2383.

Evans, D.H., 2005. The Multifunctional Fish Gill: Dominant Site of Gas Exchange, Osmoregulation, Acid-Base Regulation, and Excretion of Nitrogenous Waste. Physiol. Rev. 85, 97-177. https://doi.org/10.1152/physrev.00050.2003

FAO (Ed.), 2016. The state of world fisheries and aquaculture 2016. Contributing to food security and nutrition for all. Rome.

Glencross, B.D., Booth, M., Allan, G.L., 2007. A feed is only as good as its ingredients-a review of ingredient evaluation strategies for aquaculture feeds. Aquac. Nutr. 13, 17-34.

Goldes, S.A., Ferguson, H.W., Moccia, R.D., DAOUST, P.-Y., 1988. Histological effects of the inert suspended clay kaolin on the gills of juvenile rainbow trout, Salmo gairdneri Richardson. J. Fish Dis. 11, 23-33.

Herbert, D.W.M., Merkens, J.C., 1961. The effect of suspended mineral solids on the survival of trout. Int. J. Air Water Pollut. 5, 46-55.

Ip, Y., Chew, S., Randall, D., 2001. Ammonia toxicity, tolerance, and excretion. Fish Physiol. 20, 109-148.

Iwama, G.K., Tautz, A.F., 1981. A Simple Growth Model for Salmonids in Hatcheries. Can. J. Fish. Aquat. Sci. 38, 649-656. https://doi.org/10.1139/f81-087

Jobling, M., 2003. The thermal growth coefficient (TGC) model of fish growth: a cautionary note. Aquac. Res. 34, 581-584. https://doi.org/10.1046/j.1365-2109.2003.00859.x

Klinger, D., Naylor, R., 2012. Searching for Solutions in Aquaculture: Charting a Sustainable Course. Annu. Rev. Environ. Resour. 37, 247-276. https://doi.org/10.1146/annurev-environ-021111-161531

Knoph, M.B., Thorud, K., 1996. Toxicity of ammonia to Atlantic salmon (Salmo salar L.) in seawater-Effects on plasma osmolality, ion, ammonia, urea and glucose levels and hematologic parameters. Comp. Biochem. Physiol. A Physiol. 113, 375-381.

Kolarevic, J., Selset, R., Felip, O., Good, C., Snekvik, K., Takle, H., Ytteborg, E., Baeverfjord, G., Åsgård, T., Terjesen, B.F., 2013. Influence of long term ammonia exposure on Atlantic salmon (Salmo salar L.) parr growth and welfare. Aquac. Res. 44, 1649-1664. https://doi.org/10.1111/j.1365-2109.2012.03170.x

Lay, J.O., 2001. MALDI-TOF mass spectrometry of bacteria. Mass Spectrom. Rev. 20, 172-194. https://doi.org/10.1002/mas.10003

Levene, H., 1960. Robust test for the equality of variances, in: Olkin, I., Ghurge, S.G., Hoeffding, W., Madow, W.G., Mann, H.B. (Eds.), Contributions to Probability and Statistics. Stanford University Press, Stanford, CA, pp. 278-292.

Ling, J., Chen, S., 2005. Impact of organic carbon on nitrification performance of different biofilters. Aquac. Eng. 33, 150-162. https://doi.org/10.1016/j.aquaeng.2004.12.002 
660

Linton, T.K., Reid, S.D., Wood, C.M., 1999. Effects of a restricted ration on the growth and energetics of juvenile rainbow trout exposed to a summer of simulated warming and sublethal ammonia. Trans. Am. Fish. Soc. 128, 758-763.

Linton, T.K., Reid, S.D., Wood, C.M., 1997. The metabolic costs and physiological consequences to juvenile rainbow trout of a simulated summer warming scenario in the presence and absence of sublethal ammonia. Trans. Am. Fish. Soc. 126, 259272.

Lloyd, R., 1961. Effect of dissolved oxygen concentrations on the toxicity of several poisons to rainbow trout (Salmo gairdnerii Richardson). J. Exp. Biol. 38, 447-455.

Martins, C.I.M., Eding, E.H., Schneider, O., Rasmussen, R., Olesen, B., Plesner, L., Verreth, J.A.J., 2005. Recirculation aquaculture systems in Europe. CONSENSUS, Oostende, Belgium, Consensus Working Group. European Aquaculture Society.

McCarthy, D.H., Stevenson, J.P., Roberts, M.S., 1975. Some blood parameters of the rainbow trout (Salmo gairdneri Richardson). J. Fish Biol. 7, 215-219.

McCarthy, D.H., Stevenson, J.P., Roberts, M.S., 1973. Some blood parameters of the rainbow trout (Salmo gairdneri Richardson). J. Fish Biol. 5, 1-8.

Meade, J.W., 1985. Allowable ammonia for fish culture. Progress. Fish-Cult. 47, 135-145. Morgan, M., Tovell, P.W.A., 1973. The structure of the gill of the trout, Salmo gairdneri (Richardson). Z. Für Zellforsch. Mikrosk. Anat. 142, 147-162. https://doi.org/10.1007/BF00307029

Naylor, R.L., Goldburg, R.J., Primavera, J.H., Kautsky, N., Beveridge, M.C.M., Clay, J., Folke, C., Lubchenco, J., Mooney, H., Troell, M., 2000. Effect of aquaculture on world fish supplies. Nature 405, 1017-1024. https://doi.org/10.1038/35016500

Naylor, R.L., Hardy, R.W., Bureau, D.P., Chiu, A., Elliott, M., Farrell, A.P., Forster, I., Gatlin, D.M., Goldburg, R.J., Hua, K., Nichols, P.D., 2009. Feeding aquaculture in an era of finite resources. Proc. Natl. Acad. Sci. 106, 15103-15110. https://doi.org/10.1073/pnas.0905235106

Noble, A.C., Summerfelt, S.T., 1996. Diseases encountered in rainbow trout cultured in recirculating systems. Annu. Rev. Fish Dis. 6, 65-92. https://doi.org/10.1016/S0959-8030(96)90006-X

Pedersen, P.B., von Ahnen, M., Fernandes, P., Naas, C., Pedersen, L.-F., Dalsgaard, J., 2017. Particle surface area and bacterial activity in recirculating aquaculture systems. Aquac. Eng., Workshop on Recirculating Aquaculture Systems (III) 78, 18-23. https://doi.org/10.1016/j.aquaeng.2017.04.005

Pund, R.P., 1998. Anwendung hämatologischer Untersuchungsmethoden für Fischblut und Beeinflussung des Blutbildes von Bachforellen (Salmo trutta f. fario) durch Haltungs-und Umwelteinflüsse sowie endogene Faktoren. Freie Universität Berlin.

Qualls, R.G., Flynn, M.P., Johnson, J.D., 1983. The role of suspended particles in ultraviolet disinfection. J. Water Pollut. Control Fed. 1280-1285.

Randall, D.J., Tsui, T.K.N., 2002. Ammonia toxicity in fish. Mar. Pollut. Bull. 45, 17-23.

Redding, J.M., Schreck, C.B., Everest, F.H., 1987. Physiological Effects on Coho Salmon and Steelhead of Exposure to Suspended Solids. Trans. Am. Fish. Soc. 116, 737744. https://doi.org/10.1577/1548-8659(1987)116<737:PEOCSA>2.0.CO;2

Řehulka, J., Minařik, B., Řehulková, E., 2004. Red blood cell indices of rainbow trout Oncorhynchus mykiss (Walbaum) in aquaculture. Aquac. Res. 35, 529-546. https://doi.org/10.1111/j.1365-2109.2004.01035.x

Rojas-Tirado, P., Pedersen, P.B., Vadstein, O., Pedersen, L.-F., 2018. Changes in microbial water quality in RAS following altered feed loading. Aquac. Eng. 81, 8088. https://doi.org/10.1016/j.aquaeng.2018.03.002

Roque d'Orbcastel, E., Person-Le Ruyet, J., Le Bayon, N., Blancheton, J.-P., 2009. Comparative growth and welfare in rainbow trout reared in recirculating and flow 
through rearing systems. Aquac. Eng. 40, 79-86.

https://doi.org/10.1016/j.aquaeng.2008.11.005

Schumann, M., Brinker, A., Friedrich, C., 2018. Rheological characterization of an in vitro model for salmonid chyme to quantify changes in feed composition. Biorheology 54, 167-184. https://doi.org/10.3233/BIR-18167

Smart, G., 1976. The effect of ammonia exposure on gill structure of the rainbow trout (Salmo gairdneri). J. Fish Biol. 8, 471-475.

Smith, C.E., Piper, R.G., 1975. Lesions associated with chronic exposure to ammonia. Pathol. Fishes W E Ribelin Ed Univ. Wis. Press Madison Wis. 1975 P 497-514.

Sokal, R.R., Rohlf, J.F., 2003. Biometry: the principles and practice of statistics in biological research, 8th ed. W.H. Freemann and Company, New York.

Summerfelt, S.T., Adler, P.R., Glenn, D.M., Kretschmann, R.N., 1999. Aquaculture sludge removal and stabilization within created wetlands. Aquac. Eng. 19, 81-92.

Thurston, R.V., Russo, R.C., Luedtke, R.J., Smith, C.E., Meyn, E.L., Chakoumakos, C., Wang, K.C., Brown, C., 1984. Chronic toxicity of ammonia to rainbow trout. Trans. Am. Fish. Soc. 113, 56-73.

Timmons, M.B., Ebeling, J.M., 2010. Recirculating Aquaculture, 2nd ed. Cayuga Aqua Ventures, Ithaca, NY.

Turnbull, J., Bell, A., Adams, C., Bron, J., Huntingford, F., 2005. Stocking density and welfare of cage farmed Atlantic salmon: application of a multivariate analysis. Aquaculture 243, 121-132. https://doi.org/10.1016/j.aquaculture.2004.09.022

Unger, J., Brinker, A., 2013. Feed and treat: What to expect from commercial diets. Aquac. Eng. 53, 19-29. https://doi.org/10.1016/j.aquaeng.2012.11.012

U.S.-EPA, 2011. Environmental technology verification report. Mycometerß-test Rapid Fungi Detection and Bactiquant $\AA$-test Rapid Bacteria Detection Technologies. U.S. Environmental Protection Agency, Office of Research and Development.

Utne-Palm, A.C., 2002. Visual feeding of fish in a turbid environment: Physical and behavioural aspects. Mar. Freshw. Behav. Physiol. 35, 111-128. https://doi.org/10.1080/10236240290025644

Verdegem, M.C.J., Bosma, R.H., Verreth, J.A.J., 2006. Reducing Water Use for Animal Production through Aquaculture. Int. J. Water Resour. Dev. 22, 101-113. https://doi.org/10.1080/07900620500405544

Wedemeyer, G.A., 1996. Physiology of Fish in Intensive Culture Systems. Springer US, Boston, MA.

Wicks, B.J., Joensen, R., Tang, Q., Randall, D.J., 2002. Swimming and ammonia toxicity in salmonids: the effect of sub lethal ammonia exposure on the swimming performance of coho salmon and the acute toxicity of ammonia in swimming and resting rainbow trout. Aquat. Toxicol. 59, 55-69.

Wicks, B.J., Randall, D.J., 2002. The effect of sub-lethal ammonia exposure on fed and unfed rainbow trout: the role of glutamine in regulation of ammonia. Comp. Biochem. Physiol. A. Mol. Integr. Physiol. 132, 275-285.

Wood, C.M., 2004. Dogmas and controversies in the handling of nitrogenous wastes: Is exogenous ammonia a growth stimulant in fish? J. Exp. Biol. 207, 2043-2054. https://doi.org/10.1242/jeb.00990

Ytrestøyl, T., Aas, T.S., Åsgård, T., 2015. Utilisation of feed resources in production of Atlantic salmon (Salmo salar) in Norway. Aquaculture 448, 365-374. https://doi.org/10.1016/j.aquaculture.2015.06.023 
Figure captions:

Figure 1: Scheme of the recirculating aquaculture systems with modification for particle accumulation in the treatment system (light grey shaded).

Figure 2: Experimental setup of the rainbow trout exposure in the RAS.

Figure 3: Unionized ammonia nitrogen $\left(\mathrm{NH}_{3}-\mathrm{N}\right)$ concentration (mean, minimum (Min) and maximum values (Max)) in the control and treatment RAS during the investigation period. The dashed line shows the common limit value of $\mathrm{NH}_{3}-\mathrm{N}(0.0125 \mathrm{mg} / \mathrm{L})$ for salmonids (Timmons and Ebeling, 2010).

Figure 4: (A) Timeline of total suspended solids concentration (mean \pm S.D.) in control and treatment RAS over the experimental period. (B) Representative daily variation of total suspended solids concentration (mean \pm S.D.) in control and treatment RAS in week 12 . Samples were collected every two hours between 7:00 and 19:00 and at 23:00 (CET). Please note the axis break on the $x$-axis.

Figure 5: Absolute frequency within particle size classes (mean \pm S.E.) of the control $(n=$ 4) and treatment RAS $(n=4)$ in week 12 . All particle size classes differed significantly $(P<$ 0.001 ) between control and treatment system. Please note the axis break on the y-axis.

Figure 6: Bacteriological examination of gills (direct detection and cultivation) and spleen (cultivation) from 20 rainbow trout of the control (C) and treatment (T) RAS. ${ }^{* *}=P<0.01$; ${ }^{* * *}=P<0.0001$

Figure 7: Bacterial activity (BQV/mL, mean \pm S.D.) in the treatment and control RAS during the investigation period.

Figure 8: Linear relationship between bacterial activity $(\mathrm{BQV} / \mathrm{mL})$ and total suspended solid concentration (mg/L) for control (open symbol) and treatment RAS (solid symbol) and in sum. The dashed line shows the overall linear relationship, the solid lines show the linear relationship of the treatment and control system respectively. 
794 Highlights:

795 - Study of combined chronic effects of critical solid and unionized ammonia exposure

796 - Full control of water parameters except turbidity in replicated RAS

797 - Only minimal effects of $\mathrm{NH}_{3}-\mathrm{N}$ up to $0.05 \mathrm{mg} / \mathrm{L}$ on fish physiology

798 - No interaction effects between ammonia and suspended solid load

799 - Close linear correlation of suspended solid load and bacterial activity 


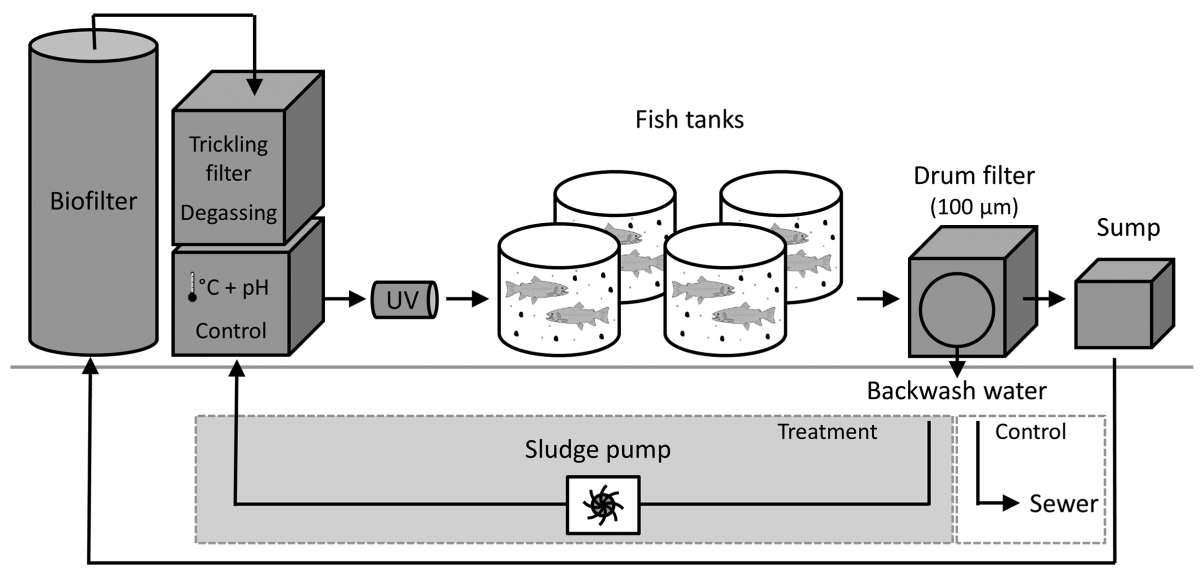

$\longrightarrow=$ Water flow direction

Figure 1 


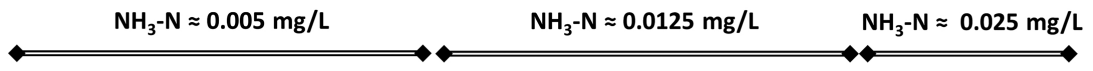

Addition of $\mathrm{NH}_{4} \mathrm{CL}$

$\mathrm{pH}$ - value around 7.5

$\mathrm{pH}$ - value around 8.0

Start

Week 5

Phase 1

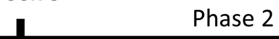

Week 10

Week 13

1
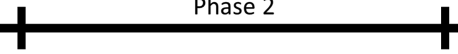

Phase 3

1. Sampling

2. Sampling

3. Sampling

4. Sampling

Increase of particle concentration to over $\mathbf{3 5} \mathbf{~ m g} / \mathrm{L}$ in the treatment RAS
Particle concentration was kept constantly over $35 \mathrm{mg} / \mathrm{L}$ in the treatment RAS

Figure 2 


\section{Control}

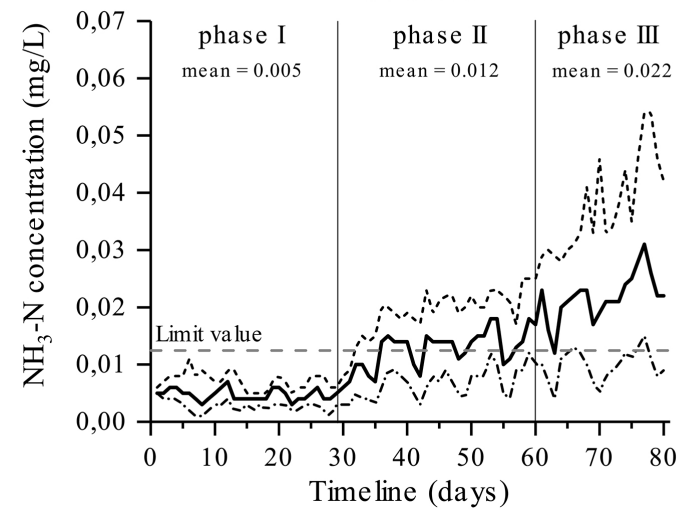

\section{Treatment}

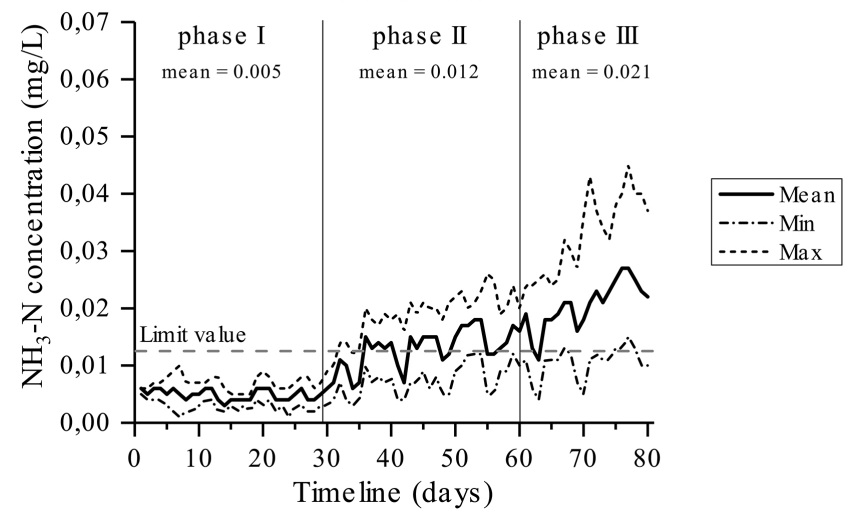

Figure 3 


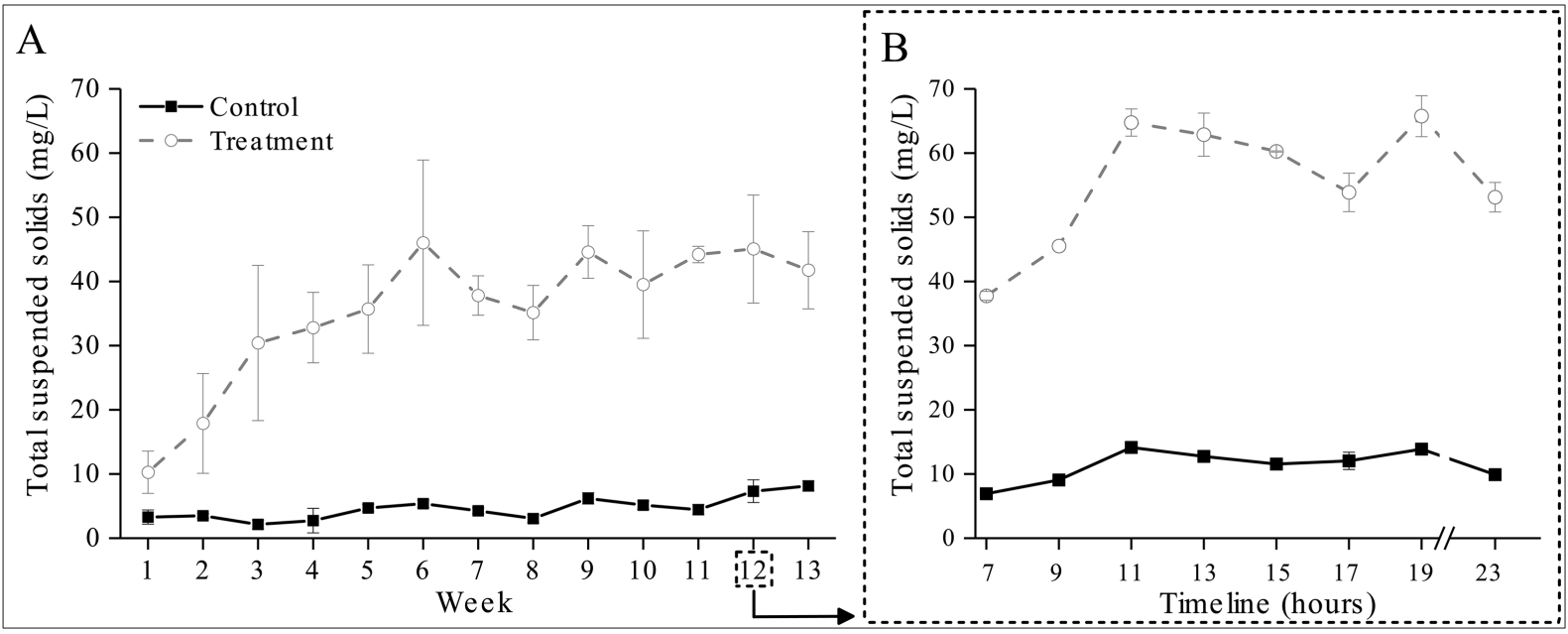

Figure 4 


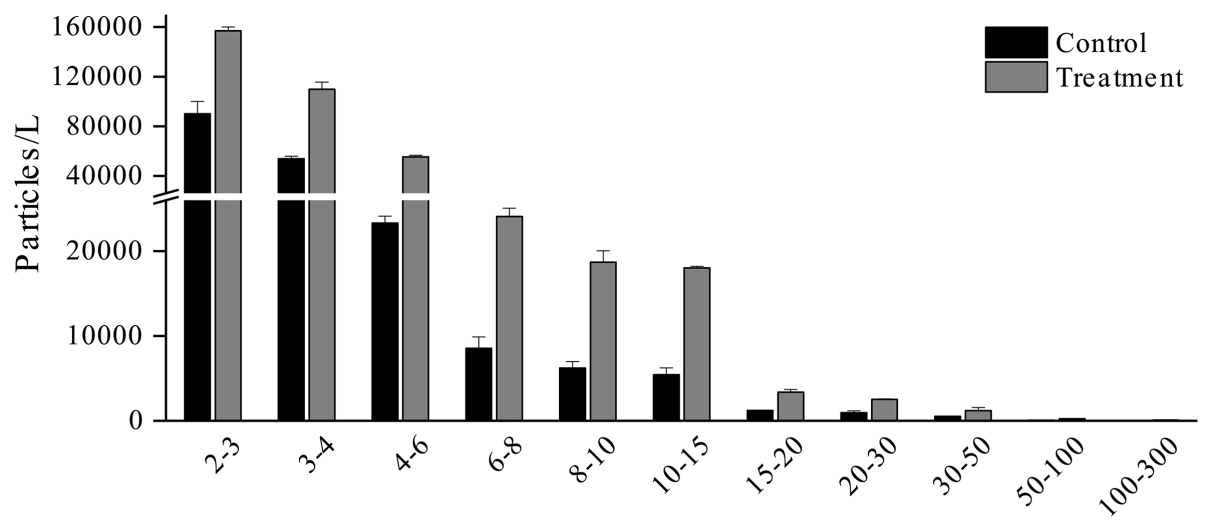

Particle size class $(\mu \mathrm{m})$

Figure 5 


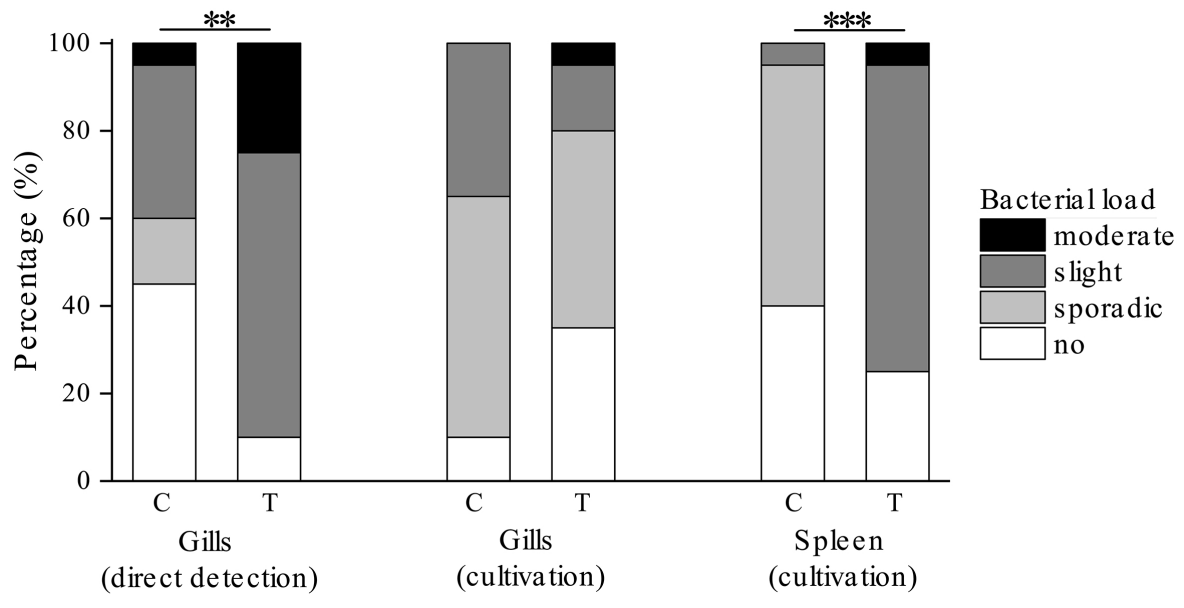

Figure 6 


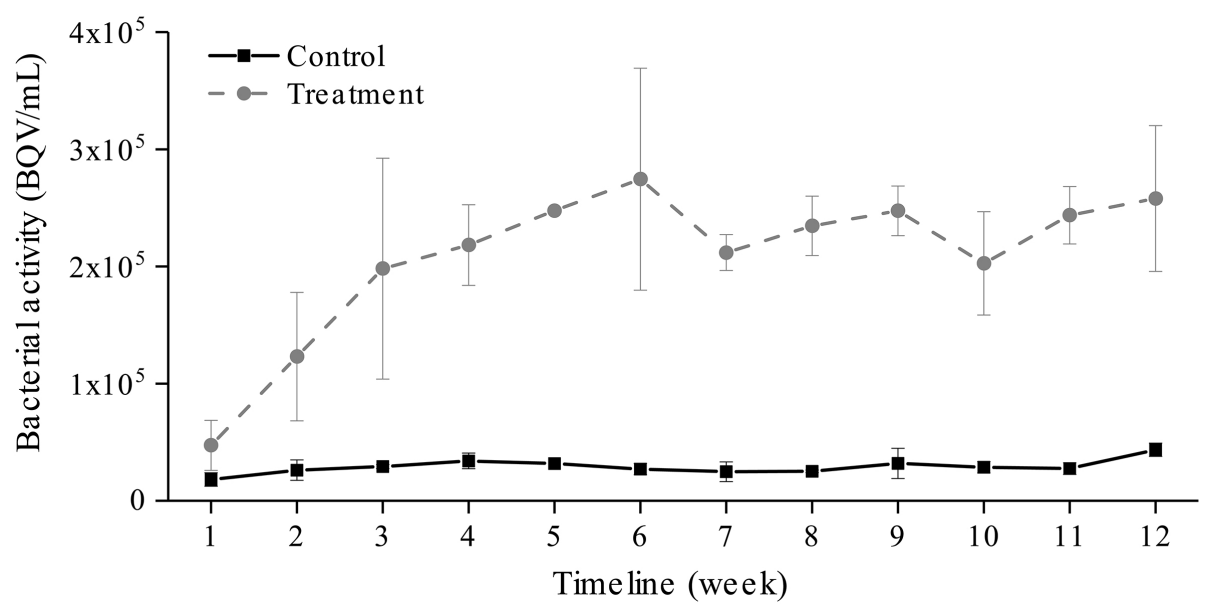

Figure 7 


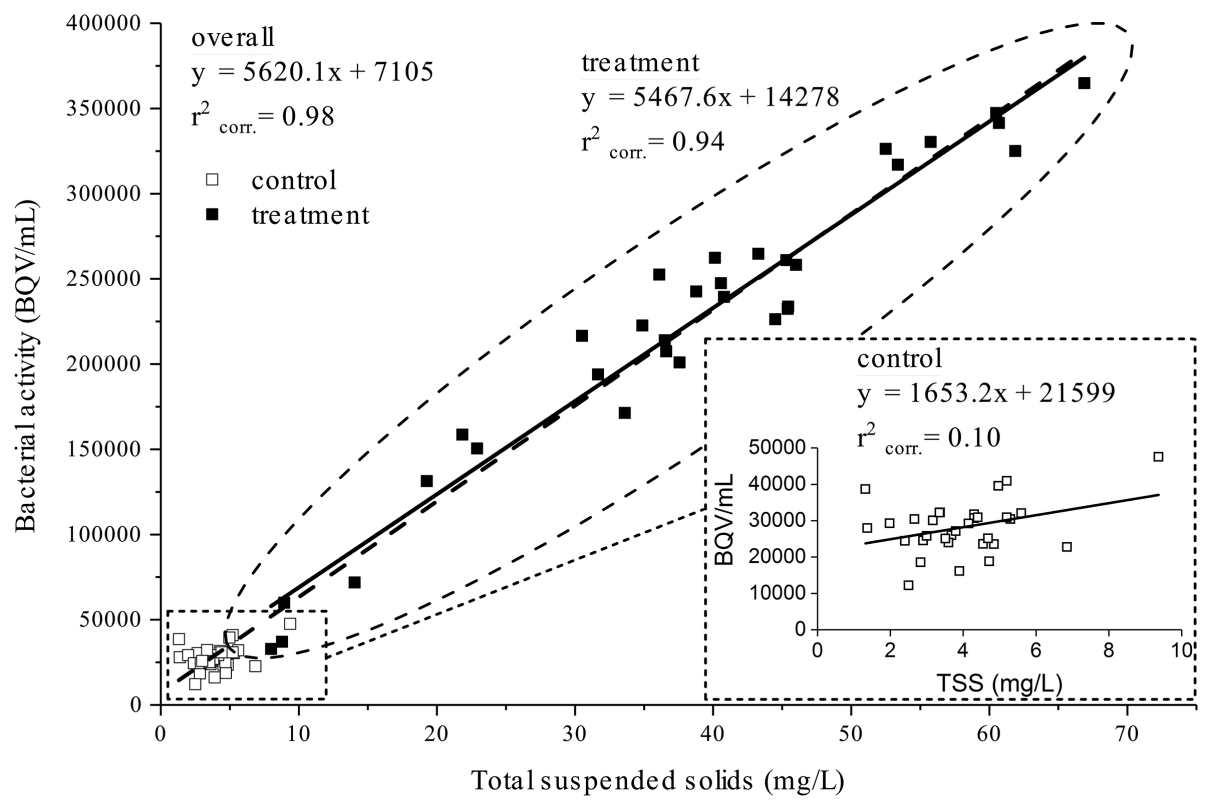

Figure 8 